Biogeosciences, 10, 4741-4750, 2013

www.biogeosciences.net/10/4741/2013/

doi:10.5194/bg-10-4741-2013

(C) Author(s) 2013. CC Attribution 3.0 License.

\title{
Growth increment periodicity in the shell of the razor clam Ensis directus using stable isotopes as a method to validate age
}

\author{
J. F. M. F. Cardoso ${ }^{1,2}$, G. Nieuwland ${ }^{1}$, R. Witbaard ${ }^{1}$, H. W. van der Veer ${ }^{1}$, and J. P. Machado ${ }^{2,3}$ \\ ${ }^{1}$ NIOZ - Royal Netherlands Institute for Sea Research, PO Box 59, 1790 AB Den Burg Texel, the Netherlands \\ ${ }^{2}$ CIIMAR/CIMAR - Interdisciplinary Centre of Marine and Environmental Research, University of Porto, Rua dos \\ Bragas 289, 4050-123 Porto, Portugal \\ ${ }^{3}$ ICBAS - Instituto de Ciências Biomédicas Abel Salazar, Laboratorio de Fisiologia Aplicada, Universidade do Porto, \\ Rua de Jorge Viterbo Ferreira 228, 4050-313 Porto, Portugal
}

Correspondence to: J. F. M. F. Cardoso (joanafcardoso@ portugalmail.com)

Received: 18 February 2013 - Published in Biogeosciences Discuss.: 6 March 2013

Revised: 31 May 2013 - Accepted: 8 June 2013 - Published: 15 July 2013

\begin{abstract}
To evaluate the role of the razor clam Ensis directus in Dutch coastal waters, understanding its population dynamics is important. As such, the age structure of the population forms a key parameter. Accurate age determination in bivalve shells is not always straightforward due to the difficulty of interpreting externally visible growth lines. In the present paper, we aimed at validating the seasonality in growth line formation using visual techniques in combination with stable oxygen and carbon isotope analyses $\left(\delta^{18} \mathrm{O}\right.$ and $\left.\delta^{13} \mathrm{C}\right)$.

High $\delta^{18} \mathrm{O}$ values in the shell coincided with growth marks on the external surface of the valve and in acetate peels of the shell's cross section. Most shell $\delta^{18} \mathrm{O}$ samples were assigned to the months from June to September. From November to March no samples were retrieved, indicating that the shell did not grow. The lowest reconstructed temperature $\left(6.3^{\circ} \mathrm{C}\right)$ suggests that $\sim 6^{\circ} \mathrm{C}$ may be the threshold temperature for growth. Nevertheless, most of the reconstructed values fell above $14.5^{\circ} \mathrm{C}$, indicating that growth occurred mainly in the summer at relatively high temperatures. Shell $\delta^{13} \mathrm{C}$ profiles followed a more or less seasonal cycle, but no direct relationship could be made between $\delta^{13} \mathrm{C}$ values and annual growth lines. Although counting external annual growth lines led to a correct estimation of age and consequently of growth rates, we recommend analysing acetate peels of cross sections to support the distinction between annual lines and disturbance lines.
\end{abstract}

\section{Introduction}

The American razor clam Ensis directus (Conrad, 1843) (also known as E. americanus, Binney, 1870) is a suspensionfeeding bivalve, common along the Atlantic coast of North America from Labrador (in Canada) to Florida (Abbott and Morris, 2001). In European waters, it was first observed in the German Bight in 1979, and it is thought to have been introduced in Europe shortly before by larval transport in ballast waters of ships that crossed the Atlantic (Von Cosel et al., 1982). Since then, E. directus has spread along the Wadden Sea and North Sea coasts, and is now found from France to Norway, Britain and the west coast of Sweden (Beukema and Dekker, 1995 and references therein; Hopkins, 2001; Minchin and Eno, 2002; Palmer, 2004; Dauvin et al., 2007). Despite the frequent events of mass mortality and variable recruitment (Mühlenhardt-Siegel et al., 1983; Beukema and Dekker, 1995; Cadée et al., 1994; Armonies and Reise, 1999), this species has managed to build up a strong population in Dutch waters (Dekker, 2011; Perdon and Goudswaard, 2007; Goudswaard et al., 2010). Presently, E. directus is the most dominant bivalve species in the Dutch coastal zone, with a total estimated biomass of around 479 million kg fresh weight in 2010 (Goudswaard et al., 2010). E. directus is not only a commercially important species (Wijsman et al., 2006) but also a food item for fish and sea ducks (Tulp et al., 2010 and references therein). Considering the increasing numbers of $E$. directus along the Dutch coast, competition with native species cannot be ruled out. 
To evaluate the importance of E. directus in Dutch coastal waters, studying its population dynamics is essential. In this respect, age is required to establish growth and mortality patterns from which productivity of a population can be derived. In razor clams, including $E$. directus, externally visible growth lines (marks) have often been used to determine individual age, whereby they were considered to correspond to a period of growth cessation (Swennen et al., 1985; Robinson and Richardson, 1998; Armonies and Reise, 1999; Fahy and Gaffney, 2001; Fahy et al., 2001; Palmer, 2004; Cardoso et al., 2009). In temperate areas, the cessation of growth coincides with the winter months, due to low food availability and low temperatures. However, sudden changes in temperature or food conditions, spawning, and other stressing factors may also lead to a temporary cessation of growth, causing deposition of growth marks during the growing season. Such growth marks may cause errors in age determination to be made on the basis of externally visible lines. In razor clams, such as E. macha, E. siliqua, and E. ensis the estimation of the age from external growth lines was found to be very unreliable due to the presence of lines formed by non-annual events (Gaspar et al., 1994; Henderson and Richardson, 1994; Barón et al., 2004). Alternative methods used for the validation of this periodicity include marking experiments (Barón et al., 2004), following the growth of cohorts over time (Beukema and Dekker, 1995; Palmer, 2004) and analysing growth lines visible in cross sections of the shell (Gaspar et al., 1994; Henderson and Richardson, 1994; Palmer, 2004). However, disturbance lines often extend internally (Haag and Commens-Carson, 2008), and therefore the periodicity of internal growth lines should also be validated. The use of isotope sclerochronology provides an objective method to make the distinction between annual and disturbance growth lines. This method has never been used to verify the periodicity of growth lines in E. directus, although it has been widely used to study growth and validate growth lines in other bivalves (e.g. Krantz et al., 1984; Jones and Quitmyer, 1996; Witbaard et al., 1994; Goodwin et al., 2001; Keller et al., 2002; Schöne and Giere, 2005; Mannino et al., 2008; Versteegh et al., 2010; Santos et al., 2012; Cardoso et al., 2013).

In the present paper, we aim to validate the seasonality in external and internal growth lines in the shell of $E$. directus to assess if the analysis of these lines gives an accurate estimation of age. For that, we determined stable oxygen and carbon isotope ratios $\left({ }^{18} \mathrm{O} /{ }^{16} \mathrm{O}\right.$ and $\left.{ }^{13} \mathrm{C} /{ }^{12} \mathrm{C}\right)$ along the longitudinal profile of shells. The ratio of stable oxygen isotopes $\left(\delta^{18} \mathrm{O}\right)$ in the shell reflects the combined effects of water temperature and water isotopic composition (Epstein et al., 1953; Grossman and $\mathrm{Ku}, 1986$ ), the latter co-varying with salinity (Epstein and Mayeda, 1953). In environments where water $\delta^{18} \mathrm{O}$ and salinity are generally constant during the lifetime of an organism, changes in shell $\delta^{18} \mathrm{O}$ record mainly changes in water temperature, whereby higher $\delta^{18} \mathrm{O}$ (enriched in ${ }^{18} \mathrm{O}$ ) corresponds to lower temperatures, and lower $\delta^{18} \mathrm{O}$ (depleted in ${ }^{18} \mathrm{O}$ ) to higher temperatures. Carbon stable isotope $\left(\delta^{13} \mathrm{C}\right)$ ratios in carbonate shell materials are influenced by metabolic factors and environmental conditions, and therefore the profiles of carbon isotope ratios in shells are less clear than $\delta^{18} \mathrm{O}$ ratios (Wefer and Berger, 1991). Although $\delta^{13} \mathrm{C}$ in the shell usually reflects seasonal variation of water $\delta^{13} \mathrm{C}$ (Mook and Vogel, 1968; Killingley and Berger, 1979; Arthur et al., 1983), respiratory $\mathrm{CO}_{2}$ originating from food metabolism may mask the seasonal variation of $\delta^{13} \mathrm{C}$ in the shell (Lorrain et al., 2004; Geist et al., 2005; McConnaughey and Gillikin, 2008; Lartaud et al., 2010; Poulain et al., 2010). Nevertheless, since metabolism is mostly related to temperature and food conditions, which in temperate habitats vary in an annual cycle, a seasonal pattern for this isotope is expected as well.

Isotope ratio profiles can therefore be used to validate whether or not identified growth bands in the shell of bivalves are formed at regular (annual) intervals and help in further interpretation of the visible lines. This approach was used in this study to identify the growth patterns in the shell of $E$. directus. To this end, we have determined whether (1) shells of $E$. directus preserve seasonal environmental records as variation in $\delta^{18} \mathrm{O}$ and $\delta^{13} \mathrm{C}$, whether (2) isotope records confirm the periodicity of band formation and can be used to estimate age of $E$. directus, and whether (3) the analysis of external and internal shell lines gives a reliable estimate of age.

\section{Materials and methods}

\subsection{Analysis of growth lines}

For the analysis of growth increments, four live bivalves without damage on the valve were selected. They were collected in April 2010, in the framework of the research programme "Building with Nature (BwN)" and the monitoring programme "LaMER" (National Institute for Waterways and Public Works of the Dutch Ministry of Infrastructure and the Environment) off the coast of Egmond aan Zee, The Netherlands $\left(52^{\circ} 23^{\prime}-52^{\circ} 38^{\prime} \mathrm{N}, 4^{\circ} 18^{\prime}-4^{\circ} 36^{\prime}\right.$ E). Shell 1 was collected at about $7 \mathrm{~km}$ off the coast (at $20.1 \mathrm{~m}$ depth), shell 2 at about $5 \mathrm{~km}$ (19.1 m depth), and shells 3 and 4 at about $2 \mathrm{~km}$ (11 m depth) (Fig. S1 in Supplement).

For each shell, the number of macroscopically visible annual lines on the external side of the valve was recorded, and shell height (defined as the distance from the dorsal to the ventral margin) was measured. Annual lines were defined as dark bands on the shell surface occurring parallel to the growing edge, which could be followed longitudinally along the shell until the umbo (Fig. 1a). Shells were scrubbed with a brush to remove adhering sediment, rinsed with distilled water, and left to air dry. Left-hand valves were placed with the concave side down in a plastic mould and embedded in epoxy resin (Poly Service, THV-500 epoxyhars and Harder 355), following Ropes (1985). Once hardened, the blocks 

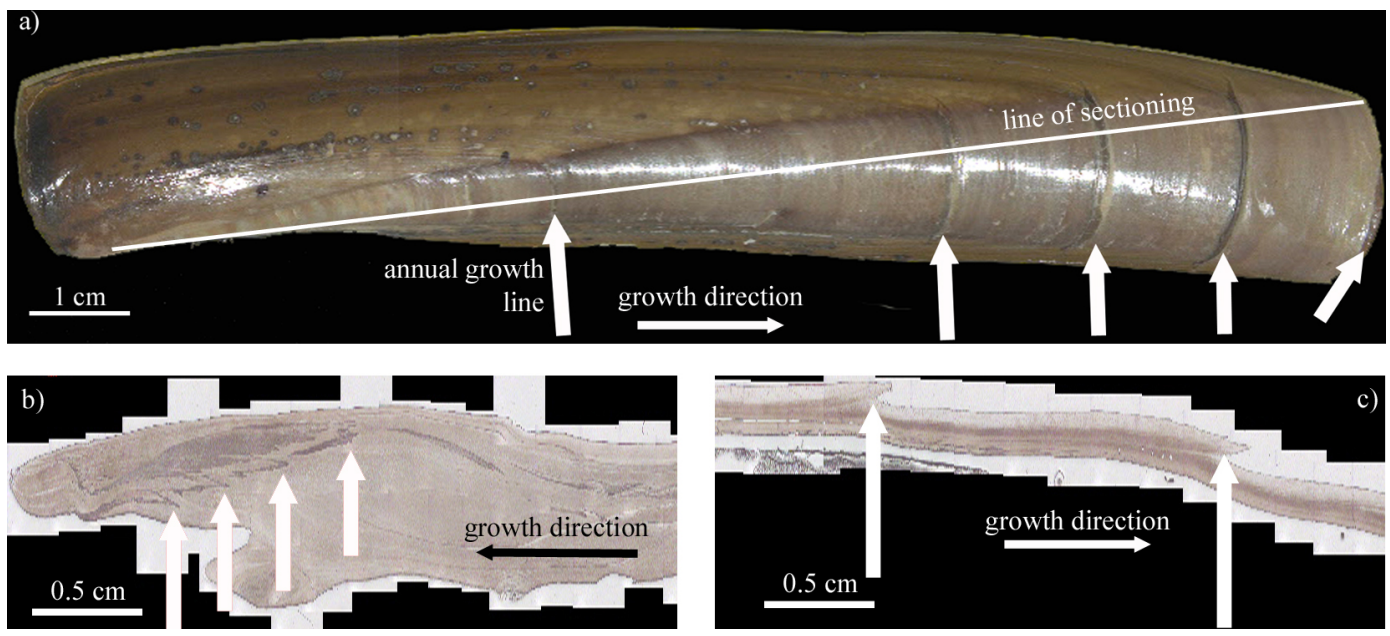

Fig. 1. Photographs of valve and cross sections of E. directus shells: (a) valve with lines identified externally as annual growth lines (arrows), (b) acetate peel of the hinge showing internal annual growth lines, and (c) acetate peel of the valve with two annual growth lines.

were sectioned longitudinally from the umbo to the growing edge (Fig. 1a), in the form of slices of about $5 \mathrm{~mm}$ thick. The surface closest to the umbo was ground flat under successively finer grit and wet-polished until no scratches were visible. Polished shell sections were submerged in $1 \mathrm{vol} \% \mathrm{HCl}$ for about $20 \mathrm{~s}$ and rinsed with distilled water. Acetate peels were prepared by covering the shell surface with drops of acetone and making a copy with a $0.1 \mathrm{~mm}$ thick sheet of cellulose acetate. With this method, the organic parts of the carbonate matrix are conserved and the carbonate parts are dissolved, resulting in a relief on the surface of the cross section, which is then transferred to the acetate sheet. Acetate peels were put on microscope slides, and photographs were taken under a microscope. In the resulting composite pictures, the number and position of the internal growth lines and growth increments were registered and compared with the external reading and later with the isotope profiles.

Internal annual lines on the acetate peel were defined as thin dark lines which could be seen in the hinge (Fig. 1b) and followed along the shell section until the external margin of the valve (Fig. 1c). Annual growth rates were determined based on the position of the internal and external lines which were confirmed to be annual by the isotope record.

\subsection{Isotopic composition}

The concave side of the right-hand valves was filled with epoxy resin to reinforce the valve and enable drilling of the valve convex (outer) side. Calcium carbonate powder was sampled using a micro sampler attached to a binocular microscope (MicroMill, New Wave Research) and equipped with a small dental drill (bit size $80 \mu \mathrm{m}$ ). Sampling was done along the external side of the valve in equally spaced intervals $(175 \mu \mathrm{m}$ around the growth lines identified externally as being annual and $300 \mu \mathrm{m}$ in between) and following the concentric external growth lines (Fig. S2 in Supplement). Calcium carbonate powder $(20-80 \mu \mathrm{g})$ was analysed for stable oxygen and carbon isotopic composition using a Thermo Finnigan MAT253 mass spectrometer coupled to a Kiel IV carbonate preparation device. Reproducibility of the external standard NBS 19 amounted to $\leq 0.1 \%$ and $\leq 0.05 \%$ o ( $1 \mathrm{SD})$ for $\delta^{18} \mathrm{O}$ and $\delta^{13} \mathrm{C}$, respectively.

In total 238-330 transects were drilled in each shell from the ventral margin to as close as possible to the umbo. Shells could not be sampled completely because the sampling transect near the umbo was often too small to yield sufficiently large carbonate samples. When the amount of calcium carbonate powder from a single drill line was not enough for isotope determination, the powder from two neighbouring transects was pooled. Measured $\delta^{18} \mathrm{O}$ shell $\left(\delta^{18} \mathrm{O}_{\mathrm{S}}\right)$ values were compared to predicted values (determined on basis of temperature and salinity data) assuming agreement with equilibrium fractionation. Since $E$. directus has an aragonitic shell (Kahler et al., 1976), the equation for biogenic aragonite by Grossman and Ku (1986) recalculated by Dettman et al. (1999) was used to calculate predicted $\delta^{18} \mathrm{O}_{\mathrm{S}}$ values:

$1000 \ln (\alpha)=2.559\left(10^{6} T^{-2}\right)+0.715$,

where $T$ is temperature in Kelvin and $\alpha$ is the fractionation factor between water and aragonite described by the equation

$\alpha=\left(1000+\delta^{18} \mathrm{O}_{\text {Aragonite }}\right) /\left(1000+\delta^{18} \mathrm{O}_{\mathrm{W}}\right)$,

whereby $\delta^{18} \mathrm{O}_{\text {Aragonite }}(\% o)$ is the $\delta^{18} \mathrm{O}$ of the shell $\left(\delta^{18} \mathrm{O}_{\mathrm{S}}\right)$ (relative to VSMOW - Vienna Standard Mean Ocean Water) and $\delta^{18} \mathrm{O}_{\mathrm{W}}(\% \circ)$ is the $\delta^{18} \mathrm{O}$ of the seawater (VSMOW). Because measured $\delta^{18} \mathrm{O}_{\mathrm{S}}$ values are usually reported relative to VPDB (Vienna Pee Dee belemnite), $\delta^{18} \mathrm{O}_{\mathrm{S}}$ values calculated in terms of VSMOW were converted to VPDB using 
the equation of Coplen et al. (1983):

$\delta^{18} \mathrm{O}_{\mathrm{VSMOW}}=1.03091 \cdot \delta^{18} \mathrm{O}_{\mathrm{VPDB}}+30.91$.

$\delta^{18} \mathrm{O}_{\mathrm{W}}$ was inferred from instrumental salinity data $(S)$ using the relationship between salinity and $\delta^{18} \mathrm{O}_{\mathrm{W}}$ described by Santos et al. (2012):

$\delta^{18} \mathrm{O}_{\mathrm{W}}=0.2333( \pm 0.02) \cdot S-7.9456( \pm 0.72)$

$\left(r^{2}=0.77, p<0.001\right)$.

This equation, developed in the Dutch Wadden Sea (approximately $50 \mathrm{~km}$ north of the sampling site), is similar to the one described by Bouillon et al. (2012), developed in the Scheldt estuary in the south of the Netherlands.

To align measured $\delta^{18} \mathrm{O}_{\mathrm{S}}$ with predicted values, a time scale was assigned to the individual data points of the shell isotopic record. For that, the distance from the dorsal margin to each drilled line was measured. Identified annual growth lines were used to delimit the beginning and end of each calendar year. For all growth records and each calendar year, dates were assigned to the measured $\delta^{18} \mathrm{O}_{\mathrm{S}}$ by first matching peaks (most positive $\delta^{18} \mathrm{O}_{\mathrm{S}}$ values) and troughs (most negative $\delta^{18} \mathrm{O}_{\mathrm{S}}$ values). Then the measured $\delta^{18} \mathrm{O}_{\mathrm{S}}$ record was shifted horizontally and matched to predicted values as closely as possible, maintaining the temporal sequence. The goodness of fit between measured and predicted values was then determined using a linear regression. Because no data on water $\delta^{13} \mathrm{C}$ or reliable relationships between water $\delta^{13} \mathrm{C}$ and environmental parameters were available for the sampled area, measured and predicted $\delta^{13} \mathrm{C}$ in the shell could not be compared.

To determine the temperature at which shell growth started and ceased, $\delta^{18} \mathrm{O}_{\mathrm{S}}$ values recorded in the shells were used to reconstruct water temperatures by solving Eq. (1) for temperature.

Unfortunately, no long-term temperature and salinity data were available from the sampled locations. It is known, however, that the area is a well-mixed zone with tidal currents up to $1.2 \mathrm{~m} \mathrm{~s}^{-1}$ (Witbaard, personal observation, 2011). Observations from one day in June 2011 have shown that there were no differences in temperature between locations over the entire water column (Witbaard, personal observation). Although the near coastal site may have a higher variability in salinity than the offshore locations due to freshwater influence, the salinity difference between inshore and offshore stations does not seem to be higher than 2-2.5 units (Witbaard, personal observation, 2011). For comparison of measured and predicted $\delta^{18} \mathrm{O}_{\mathrm{S}}$ values and reconstruction of water temperatures, observed sea surface temperature and salinity were obtained via Waterbase (http://live.waterbase. $\mathrm{nl} /$ waterbase). Daily temperature data were not available for the sampled area and period. Therefore, mean daily temperatures from 2001 to 2010 for the station "IJmuiden munitiestortplaats" $\left(52^{\circ} 32^{\prime} \mathrm{N}, 04^{\circ} 03^{\prime} \mathrm{E}\right)$ were taken (Fig. S1 in Supplement). Since no recent salinity data were available
Table 1. Summary statistics of $\delta^{18} \mathrm{O}, \delta^{13} \mathrm{C}$ and reconstructed temperature data retrieved from each $E$. directus shell.

\begin{tabular}{|c|c|c|c|c|}
\hline Shell & $\begin{array}{l}\text { Basic } \\
\text { statistics }\end{array}$ & $\begin{array}{r}\delta^{18} \mathrm{O} \\
(\% o)\end{array}$ & $\begin{array}{r}\delta^{13} \mathrm{C} \\
(\% \circ)\end{array}$ & $\begin{array}{r}\text { Reconstructed } \\
\text { temperature } \\
\left({ }^{\circ} \mathrm{C}\right)\end{array}$ \\
\hline \multirow[t]{5}{*}{1} & Min. & -0.78 & -2.32 & 8.6 \\
\hline & Max. & 1.71 & -0.12 & 20.2 \\
\hline & $\mathrm{N}$ & 311 & 311 & 311 \\
\hline & Mean & 0.05 & -1.17 & 16.2 \\
\hline & SD & 0.50 & 0.47 & 2.3 \\
\hline \multirow[t]{5}{*}{2} & Min. & -0.69 & -2.28 & 6.3 \\
\hline & Max. & 2.25 & -0.04 & 19.7 \\
\hline & $\mathrm{N}$ & 278 & 278 & 269 \\
\hline & Mean & 0.38 & -1.24 & 14.6 \\
\hline & SD & 0.53 & 0.48 & 2.5 \\
\hline \multirow[t]{5}{*}{3} & Min. & -1.39 & -2.54 & 9.9 \\
\hline & Max. & 1.09 & -0.50 & 21.5 \\
\hline & $\mathrm{N}$ & 237 & 237 & 237 \\
\hline & Mean & -0.42 & -1.40 & 16.9 \\
\hline & SD & 0.48 & 0.41 & 2.3 \\
\hline \multirow[t]{5}{*}{4} & Min. & -1.71 & -2.85 & 6.4 \\
\hline & Max. & 1.89 & 0.02 & 23.2 \\
\hline & $\mathrm{N}$ & 221 & 221 & 221 \\
\hline & Mean & -0.33 & -1.35 & 16.4 \\
\hline & SD & 0.60 & 0.44 & 2.8 \\
\hline
\end{tabular}

from the same station, mean annual salinity from 2001 to 2010 was taken for the station "Noordwijk $2 \mathrm{~km}$ " $\left(52^{\circ} 15^{\prime} \mathrm{N}\right.$, $\left.4^{\circ} 24^{\prime} \mathrm{E}\right)$ for shells 3 and 4 and "Noordwijk $10 \mathrm{~km}$ " $\left(52^{\circ} 18^{\prime} \mathrm{N}\right.$, $4^{\circ} 18^{\prime} \mathrm{E}$ ) for shells 1 and 2 (Fig. S1 in Supplement).

\section{Results}

\subsection{Inspection of growth lines and isotope profiles}

External and internal growth lines were visually analysed in each shell. The lines which were considered to be annual by visual inspection of the surface of the valve were also clearly visible in the acetate peel of the cross section (Fig. 1). In shells 1 and 3, four lines were considered to be annual by analysis of the valve and acetate peel. In shell 2, five lines were considered to be annual, while in shell 4 only one line was classified as annual.

For each shell, isotope profiles were matched with the number and position of the lines observed on the external shell surface and on the acetate peel. All four shells had similar ranges of $\delta^{18} \mathrm{O}_{\mathrm{S}}$ and $\delta^{13} \mathrm{C}_{\mathrm{S}}$ (Table 1) and showed similar profiles (Fig. 2). $\delta^{18} \mathrm{O}_{\mathrm{S}}$ records showed a truncated sinusoidal pattern. All four shells had a section with a steep decrease in values (e.g. in shell 1 between 3.0 and $3.5 \mathrm{~cm}$ from the umbo) followed by slow decrease (between 3.5 and $6.5 \mathrm{~cm}$ ) and a steep increase (more positive $\delta^{18} \mathrm{O}_{\mathrm{S}}$ observed 


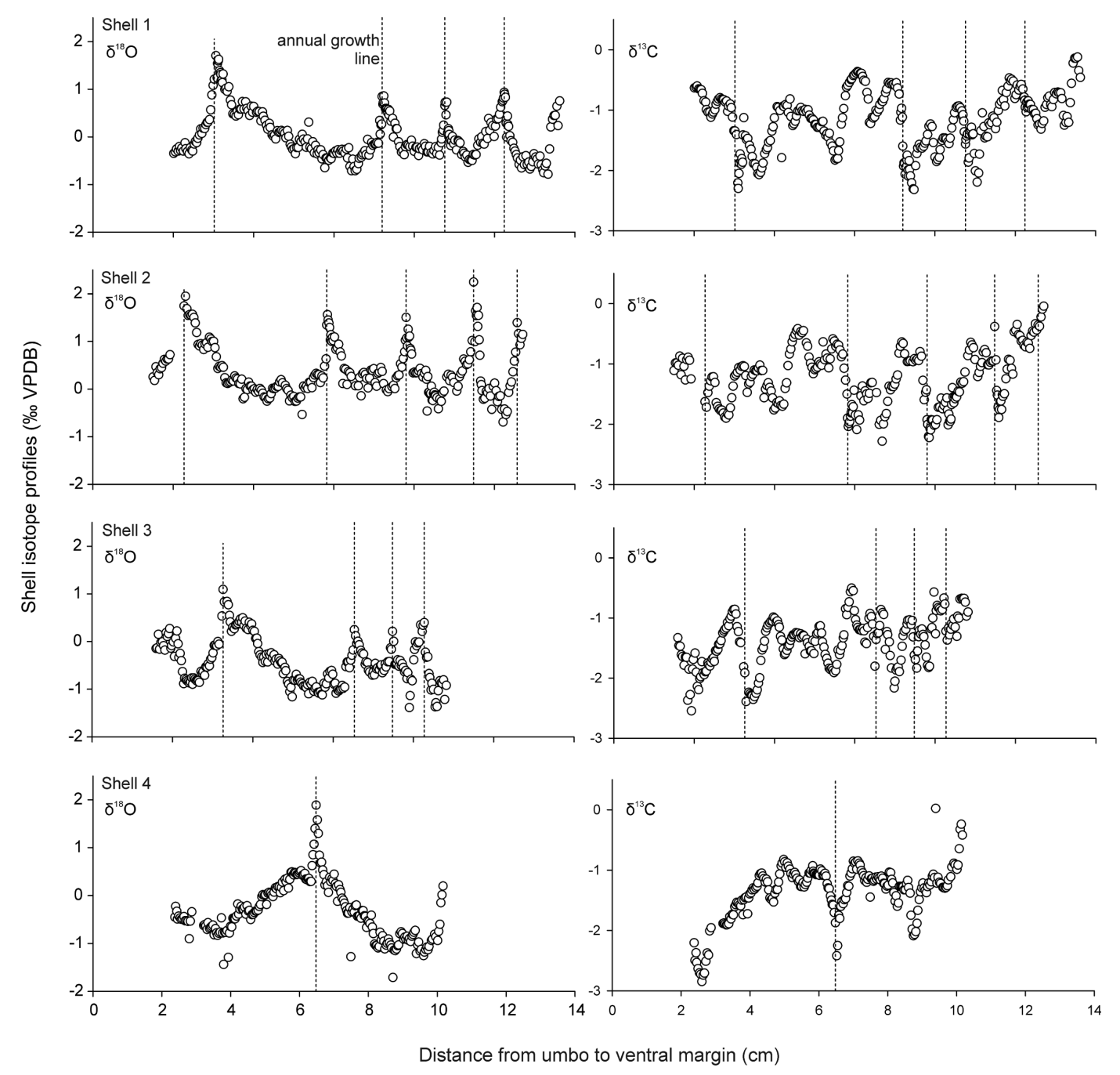

Fig. 2. Stable oxygen $\left(\delta^{18} \mathrm{O}\right.$, left panel) and carbon $\left(\delta^{13} \mathrm{C}\right.$, right panel) isotope profiles along the valve of four $E$. directus shells. Vertical dotted lines represent annual growth lines observed on the surface of the shell and in the acetate peels.

between 6.5 and $7.0 \mathrm{~cm}$ ) (Fig. 2, left panel). In all shells, high $\delta^{18} \mathrm{O}_{\mathrm{S}}$ values corresponded with the lines assigned to be annual by visual analysis of the external surface of the valve and the acetate peel. Some dark lines visible on the valve were not considered as being annual because they could not be followed along the shell. These were not seen in the acetate peels.

$\delta^{13} \mathrm{C}_{\mathrm{S}}$ records also showed a truncated sinusoidal pattern, with sections of increase in values followed by a decrease (Fig. 2, right panel). Although low $\delta^{13} \mathrm{C}_{\mathrm{S}}$ values were seen on or around the identified annual growth lines, patterns of peaks and troughs were also measured in between these annual lines. A relationship between $\delta^{13} \mathrm{C}_{\mathrm{S}}$ profiles and identified annual growth lines could not be established. Shells 1, 2 , and 3 exhibited a weak negative relationship between $\delta^{18} \mathrm{O}_{\mathrm{S}}$ and $\delta^{13} \mathrm{C}_{\mathrm{S}}$ (ANOVA, $p<0.001,0.05>r^{2}<0.11$ ), while shell 4 showed a very weak positive relationship between $\delta^{18} \mathrm{O}_{\mathrm{S}}$ and $\delta^{13} \mathrm{C}_{\mathrm{S}}$ (ANOVA, $p=0.05, r^{2}=0.01$ ).

\subsection{Measured vs. predicted $\delta^{18} \mathrm{O}_{S}$}

By matching measured and predicted values, all the $\delta^{18} \mathrm{O}_{\mathrm{S}}$ samples were assigned to the months from April to October, with most samples being assigned to June to September (Fig. 3). Measured $\delta^{18} \mathrm{O}_{\mathrm{S}}$ values showed a very good fit with the curve of predicted $\delta^{18} \mathrm{O}_{\mathrm{S}}$ (Table 2). During part of the year (November-March), which includes the period of highest predicted $\delta^{18} \mathrm{O}_{\mathrm{S}}$ values, the shell did not grow. Therefore, no isotope samples could be retrieved from the shell and the respective temperature range is completely lacking from the shell record. Annual growth lines identified on the valve and acetate peel corresponded to $\delta^{18} \mathrm{O}_{\mathrm{S}}$ samples assigned to the months of April/May.

Reconstructed seawater temperatures (calculated from measured $\delta^{18} \mathrm{O}_{\mathrm{S}}$ values) closely resembled the observed field temperatures (Fig. S3 in Supplement). Reconstructed temperatures ranged between 8.6 and $20.2^{\circ} \mathrm{C}$ in shell $1,6.3$ and 


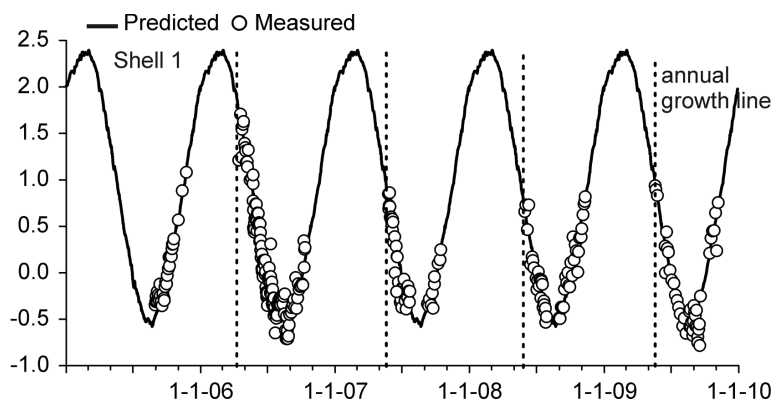

Table 2. Results of the linear regression between measured and predicted $\delta^{18} \mathrm{O}$ values in the four $E$. directus shells. $x$ is the predicted $\delta^{18} \mathrm{O} ; y$ the measured $\delta^{18} \mathrm{O}$.

\begin{tabular}{cccc}
\hline Shell & Equation & $r^{2}$ & $p$ value \\
\hline 1 & $y=0.91 \cdot x+0.02$ & 0.85 & $<0.001$ \\
2 & $y=0.87 \cdot x+0.05$ & 0.89 & $<0.001$ \\
3 & $y=0.95 \cdot x-0.10$ & 0.83 & $<0.001$ \\
4 & $y=1.01 \cdot x-0.08$ & 0.86 & $<0.001$ \\
\hline
\end{tabular}
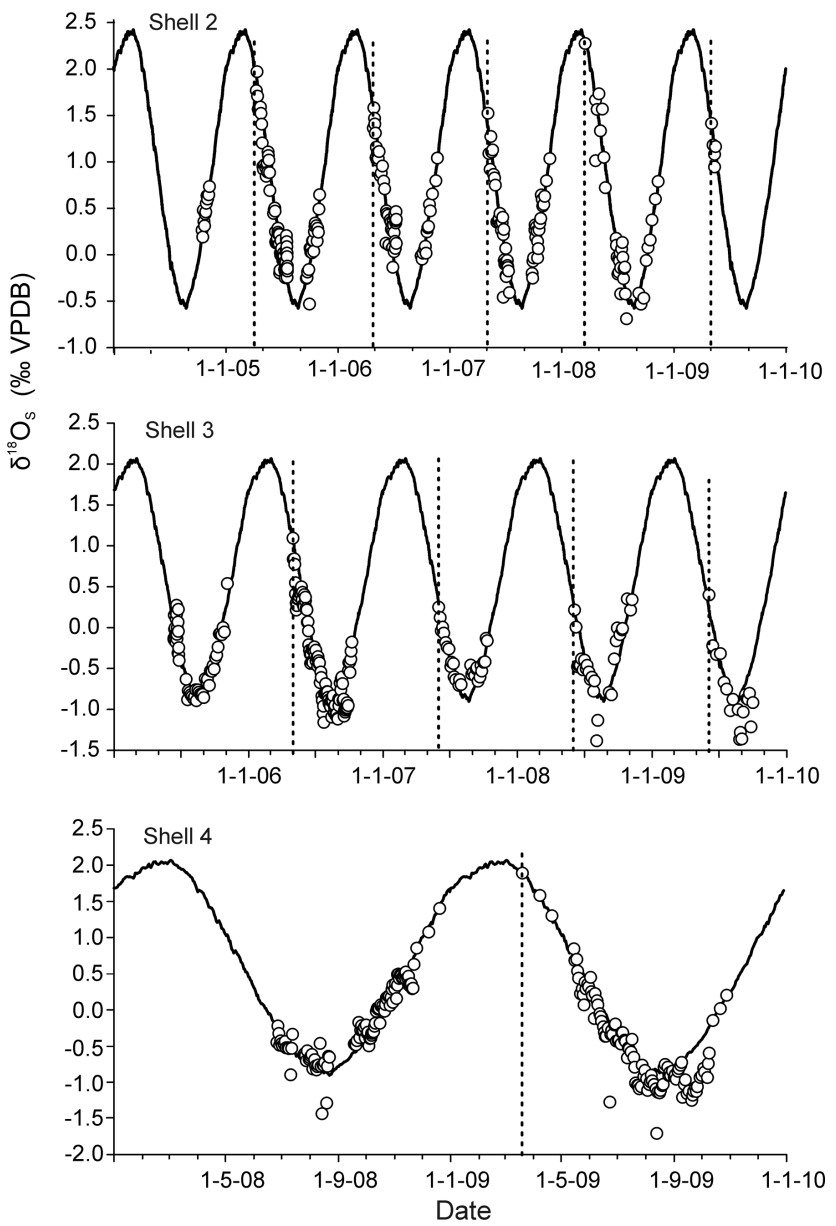

Fig. 3. Comparison of measured and predicted $\delta^{18} \mathrm{O}$ values in $E$. directus shells. Line represents predicted $\delta^{18} \mathrm{O}$ values according to Eq. (1) (see text); open circles represent measured values sampled along the valve. Vertical dotted lines represent annual growth lines observed on the surface of the shell and in the acetate peels.

$19.7^{\circ} \mathrm{C}$ in shell $2,9.9$ and $21.5^{\circ} \mathrm{C}$ in shell 3 , and 6.4 and $23.2^{\circ} \mathrm{C}$ in shell 4 (Table 1 ).

\subsection{Age estimation and growth}

The age of each shell was determined based on the growth lines which were assigned as annual by analysis of the valve and acetate peel, and validated by the isotope record. Age es-

timation took account of the fact that all shells were collected in 2010 and that significant shell growth in the field does not start before early summer, as confirmed by matching measured and predicted $\delta^{18} \mathrm{O}_{\mathrm{S}}$ values and by observations in the field (Cardoso et al., 2009; Witbaard et al., 2012). Shells 1 and 3 were considered to be $5 \mathrm{yr}$ old (year class 2005) and shell 4 was aged $2 \mathrm{yr}$ old (year class 2008). Although the most recent growth line in shell 2 was observed close to the edge, there was clear shell growth after this line. Therefore, the last complete growth increment was considered to have occurred in 2009, and shell 2 was aged 6 yr old (year class 2004).

Height-at-age and growth rate values varied among shells , and mean yearly growth rate decreased with age (Table 3 ). Growth rates during the first year of life were higher in shells 3 and 4 (closest to the coast) than in shells 1 and 2 (collected from a location further offshore). Growth rates in the following years were higher in shells 1 and 2 than in shell 3 . Because shell 4 is only $1 \mathrm{yr}$ old, it could not be used in this comparison.

\section{Discussion}

\subsection{Shell $\delta^{18} \mathrm{O}$ and growth}

$\delta^{18} \mathrm{O}_{\mathrm{S}}$ records showed truncated sinusoidal patterns suggesting seasonality in shell growth rates. Most detailed $\delta^{18} \mathrm{O}_{\mathrm{S}}$ data were collected from calcium carbonate which was deposited during the period of June to September (estimated by matching observed and predicted $\delta^{18} \mathrm{O}_{\mathrm{S}}$ values). This illustrates that growth rates are highest during this period (average growth $0.15 \mathrm{~mm} \mathrm{~d}^{-1}$, with a maximum mean of $0.22 \mathrm{~mm} \mathrm{~d}^{-1}$ observed in June). Field data collected in 2011 showed that the increase in shell height of $E$. directus in the area occurred mainly between July and August (Fig. S4 in Supplement), supporting our findings that growth is fastest during the summer.

Comparison of measured and predicted $\delta^{18} \mathrm{O}_{\mathrm{S}}$ values revealed that the most negative values (corresponding to the highest temperatures) were well represented in the shell carbonate. The most (predicted) positive values (corresponding to the lowest temperatures) were generally not all represented in the shell carbonate samples. In some shells, however, 
Table 3. Height-at-age (cm) and growth of each age class of E. directus shells.

\begin{tabular}{ccccccc}
\hline Age & \multicolumn{3}{c}{ Height-at-age $(\mathrm{cm})$} & Mean height-at-age & $\begin{array}{c}\text { Mean yearly growth } \\
( \pm \mathrm{SD})\end{array}$ \\
\cline { 2 - 5 } & shell 1 & shell 2 & shell 3 & shell 4 & $( \pm \mathrm{SD})$ & $5.27(0.78)$ \\
\hline 1 & 5.06 & 4.30 & 5.26 & 6.48 & $5.27(0.90)$ & $3.65(0.45)$ \\
2 & 9.2 & 7.84 & 8.53 & & $8.52(0.68)$ & $1.49(0.51)$ \\
3 & 10.77 & 9.80 & 9.48 & & $10.02(0.67)$ & $1.31(0.47)$ \\
4 & 12.24 & 11.48 & 10.27 & & $11.33(0.99)$ & 1.08 \\
5 & & 12.56 & & & 12.56 & \\
\hline
\end{tabular}

$\delta^{18} \mathrm{O}_{\mathrm{S}}$ data retrieved in some years covered almost the whole predicted range. Reconstructed temperatures ranged from about 6 to $23^{\circ} \mathrm{C}$. In the years $2001-2010$, mean daily sea surface temperatures measured in the field varied between 5.5 and $19.1{ }^{\circ} \mathrm{C}$ (Fig. S3 in Supplement). However, observations near the sea floor in 2011 and 2012 (Witbaard, personal observation) revealed that temperatures in February can be as low as $3.8 \pm 1.6^{\circ} \mathrm{C}$. This suggests that a temperature of $6^{\circ} \mathrm{C}$ may be the threshold for growth start. Nevertheless, most of the reconstructed values fell in the range above $14.5^{\circ} \mathrm{C}$ (around June). In 2011, highest shell growth was observed in July at temperatures around $17^{\circ} \mathrm{C}$ (Fig. S4 in Supplement), confirming that shell growth occurs mainly in the summer at relatively high temperatures. E. directus can grow at low temperatures, but the growth rate is extremely low.

The fact that shell growth occurs well above $6^{\circ} \mathrm{C}$ and that the growth stop occurs in autumn when near bottom temperatures are usually above $10^{\circ} \mathrm{C}$ (Witbaard et al., 2012; Fig. S4 in Supplement) suggests that temperature alone is not the only factor affecting shell growth. In Arctica islandica, the onset of growth is thought to be mainly determined by the seasonal cycle in primary production which is, in turn, closely regulated by the seasonal cycle in temperature (Witbaard et al., 1994). In E. directus, somatic growth starts in March/April (Cardoso et al., 2009; Witbaard et al., 2012), along with the increase in chlorophyll $a$ concentration in the seawater (Cadée and Hegeman, 2002; Witbaard et al., 2012). Gametogenesis starts earlier in the year (Cardoso et al., 2009; Witbaard et al., 2012) together with the increase in seawater temperature after the winter (Van Aken, 2008; Witbaard et al., 2012). Shell growth, however, occurs mainly later (in the beginning of the summer), and therefore growth of soft tissue and shell carbonate growth are misaligned in time. Shell growth seems to start only after the end of the main spawning (around May), suggesting that the energy used in spring for reproduction is afterwards used for shell growth. Shell growth in autumn may be hampered by low food conditions, while shell growth in spring may be hampered by a combination of low temperatures and energy allocation to reproduction.

Overall, measured $\delta^{18} \mathrm{O}_{\mathrm{S}}$ values showed a good fit with predicted values, following a seasonal pattern. In shells 3 and 4 (closer to the coast), deviations between measured and pre- dicted $\delta^{18} \mathrm{O}_{\mathrm{S}}$ values were observed in 2008 and 2009 during periods of lowest predicted $\delta^{18} \mathrm{O}_{\mathrm{S}}$ values. This resulted in higher reconstructed temperatures than the observed $10 \mathrm{yr}$ mean $\left(21.5\right.$ and $23.2^{\circ} \mathrm{C}$ vs. $\left.19.1^{\circ} \mathrm{C}\right)$. Maximum observed sea surface temperatures in $2008 / 09$ were not very different compared to the $10 \mathrm{yr}$ average (respectively $18.7^{\circ} \mathrm{C}$ and $19.9^{\circ} \mathrm{C}$; http://live.waterbase.nl/waterbase). Higher temperatures near the coast could have influenced the incorporation of $\delta^{18} \mathrm{O}$ in these shells. Unfortunately, no temperature data from these years and stations are available to support our suggestion.

An interesting fact is that, in 2007, the period with lowest predicted $\delta^{18} \mathrm{O}_{\mathrm{S}}$ values (corresponding to the highest observed temperatures) was not represented in the carbonate records. This suggests that in this year shell growth might have been constrained during a short period of time (around August). In some years two spawning periods were observed in E. directus in the Wadden Sea, the first around May and the second around August (Armonies, 1996; Cardoso et al., 2009). An extra spawning event in combination with high summer temperatures could be a reason for the growth stop in August in 2007. However, a disruption in shell growth could have also been caused by short-term events such as storms. Nevertheless, no disturbance lines were observed in any of the shells during this period.

\subsection{Shell $\delta^{13} \mathrm{C}$}

For shell building, both environmental dissolved inorganic carbon and metabolic (respired) carbon, mainly derived from carbon in the diet, are used (McConnaughey et al., 1997). In the shell of $E$. directus, $\delta^{13} \mathrm{C}_{S}$ values seem to follow a more or less sinusoidal trend although a direct relationship between $\delta^{13} \mathrm{C}_{\mathrm{S}}$ profiles and the presence of annual growth lines could not be established. This suggests that temperature partly influences variation in $\delta^{13} \mathrm{C}_{\mathrm{S}}$ values, although other factors play a role as well.

Vital effects, i.e. metabolic (resulting from respiratory $\mathrm{CO}_{2}$ ) and kinetic (acting on both $\delta^{18} \mathrm{O}_{\mathrm{S}}$ and $\delta^{13} \mathrm{C}_{\mathrm{S}}$ ) effects, can contribute to marine bivalve shell carbonate and could result in a deviation from isotopic equilibrium with the environment (Tanaka et al., 1986; Klein et al., 1996; McConnaughey et al., 1997; Lorrain et al., 2004; 
Gillikin et al., 2006, 2007; Goewert et al., 2007). In the analysed shells, the relationship between $\delta^{13} \mathrm{C}_{\mathrm{S}}$ and $\delta^{18} \mathrm{O}_{\mathrm{S}}$ was very weak, suggesting the presence of little or no kinetic effects. Although the mechanisms controlling the incorporation of $\delta^{13} \mathrm{C}$ in the shell of $E$. directus are difficult to understand, the decoupling between tissue growth, shell growth, and gametogenesis (Witbaard et al., 2012) suggests that metabolism may play a role in the intra-annual $\delta^{13} \mathrm{C}_{\mathrm{S}}$ variation. This decoupling might explain the difference in alignment of the $\delta^{13} \mathrm{C}_{\mathrm{S}}$ and $\delta^{18} \mathrm{O}_{\mathrm{S}}$ profiles relative to the position of the growth lines, reflecting a phase offset between soft tissue growth and shell growth processes. In addition, the fact that $\delta^{13} \mathrm{C}_{\mathrm{S}}$ is markedly lower at the growth line (it is usually the lowest value in each year) supports the idea that more metabolic carbon is used at this time (since metabolic carbon is very depleted in $\delta^{13} \mathrm{C}$ ).

\subsection{Validation of growth lines and age}

The highest $\delta^{18} \mathrm{O}_{\mathrm{S}}$ values coincided with the growth lines visible on both the external surface of the valve and in the acetate peel of the cross section. By matching measured and predicted $\delta^{18} \mathrm{O}_{\mathrm{S}}$ values, growth lines were confirmed to be annual. Fast growth occurred between June and September, slowing down after that until growth stopped around October-November (as revealed by the isotope record). From about November until March/April, no carbonate was deposited in the shell and the shell did not grow. It is not until shell growth resumes in the following growing season that a line corresponding to the preceding period of slow growth becomes clearly visible. The results thus suggest that annual growth lines in E. directus are formed due to a growth cessation which starts in autumn.

Since shells were sampled in April 2010 and growth starts in late spring (Cardoso et al., 2009; Fig. S4 in Supplement), all $\delta^{18} \mathrm{O}_{\mathrm{S}}$ values observed between the last growth line and the shell edge were considered to belong to the growing season of 2009. Therefore, these shells were considered to be $1 \mathrm{yr}$ older than the number of lines counted $(5 \mathrm{yr}$ old for shells 1 and 3, 6 yr for shell 2, and 2 yr old for shell 4).

In the Wadden Sea, the maximum reported age of $E$. directus was $7 \mathrm{yr}$ old (Armonies and Reise, 1999), although it is considered that most individuals do not become older than 2-4 yr (Armonies en Reise, 1999; Cardoso et al., 2009). The life span of this species along the Dutch coast seems to be higher, although an analysis of a larger sample size is required to support this suggestion.

Growth rates calculated using isotope sclerochronology were similar to those calculated by analysis of external shell lines and acetate peels. The fact that growth rates during the first year of life were higher closer to the coast, and that the opposite was observed in the following years, suggests that juvenile growth is better near the coast, while conditions for growth of adults are better offshore. During their first year of life, E. directus from the Dutch Wadden Sea reached an average size of $6.4 \mathrm{~cm}$ (Beukema and Dekker, 1995), a similar growth rate to the one observed in this study near the coast (in shells 3 and 4). However, shell growth observed for the following years was lower than observed in the Dutch Wadden Sea, being more similar to the growth observed in the German Wadden Sea $(\sim 8,10$, and $12 \mathrm{~cm}$ at an age of 2, 3, and $4 \mathrm{yr}$, respectively; Swennen et al., 1985). In contrast, shell growth in the present study was in general higher than that observed off the English east coast (Palmer, 2004). The mean annual temperature pattern in the Dutch Wadden Sea and off the Dutch North Sea coast is similar (varying between about $5^{\circ} \mathrm{C}$ in winter and $20^{\circ} \mathrm{C}$ in summer; http://www.nioz.nl; http://live.waterbase.nl/waterbase). This suggests that differences in food conditions between areas may cause the observed differences in growth. Densitydependent growth of $E$. directus was suggested for the English coast (Palmer, 2004). Average densities near stations 3 and 4 of this study were also much higher than densities observed by Beukema and Dekker (1995) in the Dutch Wadden Sea $\left(\sim 184\right.$ ind $^{-2}$ at the coast vs. $<10$ ind $\mathrm{m}^{-2}$ in the Wadden Sea; Beukema and Dekker, 1995; Witbaard et al., 2012). Therefore, the lower growth observed at the Dutch coast could be due to higher densities, causing lower food availability. Since $E$. directus shows large inter-annual variability in growth (Dekker, 2011; Daan and Mulder, 2006; Perdon and Goudswaard, 2007), the observed differences in growth between locations could be a reflection of densitydependent growth.

Based on our results, we conclude that counting annual growth lines on the external side of the valve as well as in the cross section of the shell of $E$. directus leads to an accurate estimation of the number of annual winter lines. Hence, age and consequently growth rates can be determined with sufficient accuracy. Nevertheless, to support the identification of annual lines, we recommend analysing acetate peels of the cross section as well. When analysing populations from areas with very different environmental conditions, this type of analysis should be combined with isotope sclerochronology.

\section{Supplementary material related to this article is available online at: http://www.biogeosciences.net/10/ 4741/2013/bg-10-4741-2013-supplement.pdf.}

Acknowledgements. The authors would like to thank Paul Butler, David Goodwin and David Gillikin for their comments and suggestions in previous versions of the manuscript. The authors also thank Evaline van Weerlee for helping with the isotope analysis, and Valeska Borges for preparing the shells for analysis. This research was part of the project "Determination of Dynamic Energy Budget (DEB) model parameters for Ensis directus" funded by the "Monitoring and Evaluation Programme Sandmining" of the National Institute for Waterways and Public Works of the 
Dutch Ministry for Infrastructure and Environment (RWS) and the LaMER Foundation. Analysed shells were collected within the research programmes "Building with Nature, program NTW.3.1." and "RWS-LaMer Long Deployment (LM-006588/LM-10092)". Joana Cardoso was partly funded by Fundação para a Ciência e a Tecnologia (FCT, Portugal) and Fundo Social Europeu (POPH/FSE) (grant no. SFRH/BPD/ 34773/2007).

Edited by: D. Gillikin

\section{References}

Abbott, R. T. and Morris, P. A.: Shells of the Atlantic and Gulf Coasts and the West Indies, Peterson Field Guides, Houghton Mifflin, Boston, 2001.

Armonies, W.: Changes in distribution patterns of 0-group bivalves in the Wadden Sea: byssus-drifting releases juveniles from constraints of hydrography, J. Sea Res., 35, 2323-2334, 1996.

Armonies, W. and Reise, K.: On the population development of the introduced razor clam Ensis americanus near the island of Sylt (North Sea), Helgol. Meeresunters., 52, 291-300, 1999.

Arthur, M. A., Williams, D. F., and Jones, D. S.: Seasonal temperature-salinity changes and thermocline development in the Mid-Atlantic Bight as recorded by the isotopic composition of bivalves, Geology, 11, 655-659, 1983.

Barón, P. J., Real, L. E., Ciocco, N. F., and Re, M. E.: Morphometry, growth and reproduction of an Atlantic population of the razor clam Ensis macha (Molina, 1782), Sci. Mar., 68, 211-217, 2004.

Beukema, J. J. and Dekker, R.: Dynamics and growth of a recent invader into European coastal waters: The American razor clam, Ensis directus, J. Mar. Biol. Assoc. UK, 75, 351-362, 1995.

Bouillon, S., Connelly, R. M., and Gillikin, D. P.: Use of stable isotopes to understand food webs and ecosystem functioning in estuaries, in: Treatise on Estuarine and Coastal Science, edited by: Wolanski, E. and McLusky, D. S., 7, 143-173, 2012.

Cadée, G. C. and Hegeman, J.: Phytoplankton in the Marsdiep at the end of the 20th century: 30 years monitoring biomass, primary production, and Phaeocystis blooms, J. Sea Res., 48, 97-110, 2002.

Cadée, G. C., Cadée-Coenen, J., and Witte, J. I. J.: Massale sterfte van Ensis directus op de Schanserwaard en elders blijft raadselachtig, Corresp.-blad Ned. Malac. Ver., 279, 86-93, 1994.

Cardoso, J. F. M. F., Witte, J. IJ., and Van der Veer, H. W.: Reproductive investment of the American razor clam Ensis americanus in the Dutch Wadden Sea, J. Sea Res., 62, 295-298, 2009.

Cardoso, J. F. M. F., Santos, S., Witte, J. I. J., Witbaard, R., Van der Veer, H. W., and Machado, J. P.: Age determination in the bivalve Macoma balthica: validation of the seasonality in growth lines using stable isotopes and trace elements, J. Sea Res., in press, doi:10.1016/j.seares.2012.09.006, 2013.

Coplen, T. B., Kendall, C., and Hopple, J.: Comparison of stable isotope reference samples, Nature, 302, 236-238, 1983.

Daan, R. and Mulder, M.: The macrobenthic fauna in the Dutch sector of the North Sea in 2005 and a comparison with previous data, NIOZ-Rapport 2006-3, 2006.

Dauvin, J. C., Ruellet, T., Thiebaut, E., Gentil, F., Desroy, N., Janson, A. L., Duhamel, S., Jourde, J., and Simon, S.: The presence of Melinna palmata (Annelida : Polychaeta) and Ensis directus (Mollusca : Bivalvia) related to sedimentary changes in the Bay of Seine (English Channel, France), Cah. Biol. Mar., 48, 391401, 2007.

Dekker, R.: Macrozoobenthosonderzoek MWTL, voor- en najaar 2009, Waterlichaam: Waddenzee (Balgzand en sublitorale westelijke Waddenzee), NIOZ-Rapport 2011-1, 2011.

Dettman, D. L., Reische, A. K., and Lohmann, K. C.: Controls on the stable isotope composition of seasonal growth bands in aragonitic fresh-water bivalves (unionidae), Geochim. Cosmochim. Ac., 63, 1049-1057, 1999.

Epstein, S. and Mayeda, T.: Variation of ${ }^{18} \mathrm{O}$ content of waters from natural sources, Geochim. Cosmochim. Ac., 4, 213-224, 1953.

Epstein, S., Buchsbaum, R., Lowenstam, H. A., and Urey, H. C.: Revised carbonate - water isotopic temperature scale, Geol. Soc. Am. Bull., 64, 1315-1326, 1953.

Fahy, E. and Gaffney, J.: Growth statistics of an exploited razor clam (Ensis siliqua) bed at Gormanstown, Co Meath, Ireland, Hydrobiologia, 465, 139-151, 2001.

Fahy, E., Norman, M., Browne, R., Roantree, V., Pfeiffer, N., Stokes, D., Carroll, J., and Hannaffy, O.: Distribution, population structure, growth and reproduction of the razor clam Ensis arcuatus (Jeffreys) (Solenaceae) in coastal waters of western Ireland, Irish Fish. Investig., 10, 1-30, 2001.

Gaspar, M. B., Richardson, C. A., and Monteiro, C. C.: The effects of dredging on shell formation in the razor clam Ensis siliqua from Barrinha, Southern Portugal, J. Mar. Biol. Assoc. UK, 74, 927-938, 1994.

Geist, J., Auerswald, K., and Boom, A.: Stable carbon isotopes in freshwater mussel shells: environmental record or marker for metabolic activity, Geochim. Cosmochim. Ac., 69, 3545-3554, 2005.

Gillikin, D. P., Lorrain, A., Bouillon, S., Willenz, P., and Dehairs, F.: Stable carbon isotope composition of Mytilus edulis shells: relation to metabolism, salinity, $\delta^{13} \mathrm{C}_{D I C}$, and phytoplankton, Org. Geochem., 37, 1371-1382, 2006.

Gillikin, D. P., Lorrain, A., Meng, L., and Dehairs, F.: A large metabolic carbon contribution to the $\delta^{13} \mathrm{C}$ record in marine aragonitic bivalve shells, Geochim. Cosmochim. Ac., 71, 2936-2946, 2007.

Goewert, A., Surge, D., Carpenter, S. J., and Downing, J.: Oxygen and carbon isotope ratios of Lampsilis cardium (Unionidae) from two streams in agricultural watersheds of Iowa, USA, PALAEO, 252, 637-648, 2007.

Goodwin, D. H., Flessa, K. W., Schöne, B. R., and Dettman, D. L.: Cross-calibration of daily growth increments, stable isotope variation and temperature in the Gulf of California bivalve mollusk Chione cortezi: Implications for paleoenvironmental analysis., PALAIOS, 16, 387-398, 2001.

Goudswaard, P. C., Perdon, K. J., Kesteloo, J. J., Jol, J., van Zweeden, C., Hartog, E., Jansen, J. M. J., and Troost, K.: Schelpdieren in de Nederlandse kustwateren, een kwantitatieve en kwalitatieve bestandsopname in 2010, IMARES Wageningen UR, Report C099/10, 2010.

Grossman, E. L. and Ku, T. L.: Oxygen and carbon isotope fractionation in biogenic aragonite - temperature effects, Chem. Geol., 59, 59-74, 1986.

Haag, W. R. and Commens-Carson, A. M.: Testing the assumption of annual shell ring deposition in freshwater mussels, Can. J. Fish. Aquat. Sci., 65, 493-508, 2008. 
Henderson, S. M. and Richardson, C. A.: A comparison of the age, growth rate and burrowing behaviour of the razor clams, Ensis siliqua and E. ensis, J. Mar. Biol. Assoc. UK, 74, 939-954, 1994.

Hopkins, C. C. E.: Actual and potential effects of introduced marine organisms in Norwegian waters, including Svalbard, Directorate for Nature Management, Trondheim, Norway, 2001.

Jones, D. S. and Quitmyer, I. R.: Marking time with bivalve shells: Oxygen isotopes and season of annual increment formation, PALAIOS, 11, 340-346, 1996.

Kahler, G. A., Sass, R. L., and Fisher Jr., F. M. : The fine structure and crystallography of the hinge ligament of Spisula solidissima (Moilusca: Bivaivia: Mactridae), J. Comp. Physiol., 109, 209220, 1976.

Keller, N., Del Piero, D., and Longinelli, A.: Isotopic composition, growth rates and biological behaviour of Chamelea gallina and Callista chione from the Gulf of Trieste (Italy), Mar. Biol., 140, 9-15, 2002.

Killingley, J. S. and Berger, W. H.: Stable isotopes in a mollusk shell: detection of upwelling events, Science, 205, 186-188, 1979.

Klein, R. T., Lohmann, K. C., and Thayer, C. W.: Sr/Ca and ${ }^{13} \mathrm{C} /{ }^{12} \mathrm{C}$ ratios in skeletal calcite of Mytilus trossulus: covariation with metabolic rate, salinity, and carbon isotopic composition of seawater, Geochim. Cosmochim. Ac., 60, 4207-4221, 1996.

Krantz, D. E., Jones, D. S., and Williams, D. F.: Growth rates of the sea scallop Plactopecten magellanicus, determined from ${ }^{18} \mathrm{O} /{ }^{16} \mathrm{O}$ record in shell calcite, Biol. Bull., 167, 186-199, 1984.

Lartaud, F., Emmanuel, L., Rafelis, M., Ropert, M., Labourdette, N., Richardson, C. A., and Renard, M.: A latitudinal gradient of seasonal temperature variation recorded in oyster shells from the coastal waters of France and The Netherlands, Facies, 56, 13-25, 2010.

Lorrain, A., Paulet, Y.-M., Chauvaud, L., Dunbar, R., Mucciarone, D., and Fontugne, M.: $\delta^{13} \mathrm{C}$ variation in scallop shells: increasing metabolic carbon contribution with body size, Geochim. Cosmochim. Ac., 68, 3509-3519, 2004.

Mannino, M. A., Thomas, K. D., Leng, M. J., and Sloane, H. J.: shell growth and oxygen isotopes in the topshell Osilinus turbinatus: resolving past inshore sea surface temperatures, GeoMar. Lett., 28, 309-325, 2008.

McConnaughey, T. A. and Gillikin, D. P.: Carbon isotopes in mollusk shell carbonates, Geo-Mar. Lett., 28, 287-299, 2008.

McConnaughey, T. A., Burdett, J., Whelan, J. F., and Paull, C. K.: Carbon isotopes in biological carbonates: respiration and photosynthesis, Geochim. Cosmochim. Ac., 61, 611-622, 1997.

Minchin, D. and Eno, C.: Exotics of coastal and inland waters of Ireland and Britain, in: Invasive aquatic species of Europe: distribution, impacts and management, edited by: Leppäkoski, E., Gollasch, S., and Olenin, S., 267-275, 2002.

Mook, W. G. and Vogel, J. C.: Isotopic equilibrium between shells and their environment, Science, 159, 874-875, 1968.

Mühlenhardt-Siegel, U., Dörjes, J., and Von Cosel, R.: Die Amerikanische schwertmuschel Ensis directus (Conrad) in der Deutschen Bucht, II. Populationsdynamik, Senck. Marit., 15, 93110, 1983.

Palmer, D. W.: Growth of the razor clam Ensis directus, an alien species in the Wash on the east coast of England, J. Mar. Biol. Assoc. UK, 84, 1075-1076, 2004.
Perdon, K. J. and Goudswaard, P. C.: Mesheften (Ensis directus), halfgeknotte strandschelpen (Spisula subtruncata) en kokkels (Cerastoderma edule) in de Nederlandse kustwateren in 2007, IMARES Report C087/07, 2007.

Poulain, C., Lorrain, A., Mas, R., Gillikin, D. P., Dehairs, F., Robert, R., and Paulet, Y.-M.: Experimental shift of diet and DIC stable carbon isotopes: Influence on shell $\delta^{13} \mathrm{C}$ values in the Manila clam Ruditapes philippinarum, Chem. Geol., 272, 75-82, 2010.

Robinson, R. F. and Richardson, C. A.: The direct and indirect effects of suction dredging on a razor clam (Ensis arcuatus) population, ICES J. Mar. Sci., 55, 970-977, 1998.

Ropes, J. W.: Modern methods to age oceanic bivalves, Nautilus, 99, 53-57, 1985.

Santos, S., Cardoso, J. F. M. F., Borges, V., Luttikhuizen, P. C., and Van der Veer, H. W.: Isotopic fractionation between seawater and the shell of Scrobicularia plana (Bivalvia) and its use for age validation, Mar. Biol., 159, 601-611, 2012.

Schöne, B. R. and Giere, O.: Growth increments and stable isotope variation in shells of the deep-sea hydrothermal vent bivalve mollusk Bathymodiolus brevior from the North Fiji Basin, Pacific Ocean, Deep-Sea Res. Pt. I, 52, 1896-1910, 2005.

Swennen, C., Leopold, M. F., and Stock, M.: Notes on growth and behavior of the American razor clam Ensis directus in the Wadden Sea and the predation on it by birds, Helgol. Meeresunters., 39, 255-261, 1985.

Tanaka, N., Monaghan, M. C., and Rye, D. M.: Contribution of metabolic carbon to mollusc and barnacle shell carbonate, Nature, 320, 520-523, 1986.

Tulp, I., Craeymeersch, J., Leopold, M., van Damme, C., Fey, F., and Verdaat, H.: The role of the invasive bivalve Ensis directus as food source for fish and birds in the Dutch coastal zone, Estuar. Coast. Shelf S., 90, 116-128, 2010.

Van Aken, H.: Variability of the water temperature in the western Wadden Sea on tidal to centennial time scales, J. Sea Res., 60, 227-234, 2008.

Versteegh, E. A. A., Vonhof, H. B., Troelstra, S. R., Kaandorp, R. J. G., and Kroon, D.: Seasonally resolved growth of freshwater bivalves determined by oxygen and carbon isotope shell chemistry, Geochem. Geophy. Geosy., 11, Q08022, doi:10.1029/2009GC002961, 2010.

Von Cosel, R., Dörjes, J., and Mühlenhardt-Siegel, U.: Die Amerikanische schwertmuschel Ensis directus (Conrad) in der Deutschen Bucht. I. Zoogeographie und taxonomie im vergleich mit den einheimischen schwertmuschel-arten, Senck. Marit., 14, 147-173, 1982.

Wefer, G. and Berger, W. H.: Isotope palaeontology: growth and composition of extant calcareous species, Mar. Geol., 100, 207248, 1991.

Wijsman, J. W. M., Kesteloo, J. J., and Craeymeersch, J. A.: Ecologie, visserij en monitoring van mesheften in de Voordelta, Nederlands Instituut voor Visserij Onderzoek (RIVO), Yerseke, Report C009/06, 2006.

Witbaard, R., Jenness, M. I., van der Borg, K., and Ganssen, G.: Verification of annual growth increments in Arctica islandica $\mathrm{L}$. from the North Sea by means of oxygen and carbon isotopes, Neth. J. Sea Res., 33, 91-101, 1994.

Witbaard, R., Duineveld, G. C. A., and Bergman, M.: Dynamics and growth of Ensis directus in the near coastal zone of Egmond, in relation to environmental conditions, NIOZ-report 2012-7, 2012. 